\title{
The level of research and development sector involvement in the implementation of regions' innovative growth
}

\author{
Natalia Fadeykina \\ Siberian Academy of Finance and Banking \\ Rector, chair \\ Novosibirsk, Russia \\ rektor@nnet.ru
}

\author{
Timur Bieiadovskii \\ Siberian Academy of Finance and Banking \\ Strategic and innovation management department \\ Novosibirsk, Russia \\ timurbyadovski@gmail.com
}

\author{
Svetlana Malina \\ Siberian Academy of Finance and Banking \\ Strategic and innovation management department \\ Novosibirsk, Russia \\ malinasveta2012@gmail.com
}

\begin{abstract}
The activities of scientific organizations performing research, development and technological work for civil purposes, and interacting with business and other key representatives of the national innovation system, occurring at the regional level, are considered. On the basis of the proposed methodological tools, the state of integration interaction between scientific organizations and participants of innovation activity is assessed in the framework of technological platforms and innovative territorial clusters functioning. The necessity of further revealing the reasons that determine the unclaimedness of these network forms for the implementation of the state innovation policy is substantiated.
\end{abstract}

Keywords - innovative territorial clusters, technological platform, scientific organizations, FASO, RAS

\section{INTRODUCTION}

The use of growth factors based on the results of scientific and technological progress is a characteristic feature of modern economic models $[1 ; 2]$. As international experience proves, the implementation of innovation development strategies should be carried out at all levels of government: federal, regional, municipal and corporate. This should be one of the ensuring national innovation policy principles.

The role of scientific organizations as key participants in the national (including regional) innovation system, called upon (in the context of implementing the ecosystem ideology $[3,4])$ to perform fundamental, applied, exploratory research and technological work, generate new knowledge, commercialize the results of intellectual activity in order to compress and ensure the continuous movement of the innovations life cycle, especially in the priority areas of the high-tech sector development which is based on modern technological styles, is unusually high.

Considering the sector of Russian research organizations, one cannot ignore the Federal Agency of Scientific Organizations (FASO), which includes the three-hundred-year history of the Russian Academy of Sciences (RAS), its intellectual and technological opportunities [5]. Scientific organizations subordinating to the FASO are one of the main sources of knowledge generation, on the basis of which solutions are implemented that most effectively meet the great challenges of our time.

The RAS organizations throughout the whole period of their existence were oriented to the needs of production and economic activity. As an example, it is enough to mention the illustrious words of the famous Academician of the USSR Academy of Sciences Petr Leonidovich Kapitsa: "This work is remarkable in that it arose ... from the idea of giving the country cheap oxygen" [6, p. 252]. It is from this formulation, which has national importance, that Kapitsa began his scientific and engineering activities after returning from England.

Currently, the transfer dynamics of the intellectual activity results (we're talking about domestic practice) is characterized by low rates, the openness of participants in the innovation cycle can be traced. To take advantage of the knowledge that can ensure sustainable development, it is necessary to create conditions that stimulate the transformation of the fundamental and applied research results, which is one of the 
main methodological principles for the functioning of the national (regional) innovation system. In the focus of the above-mentioned task, the research of the scientific organization's interaction with the network structures of the innovation process, in particular, technological platforms [7] and innovative territorial clusters [8] is becoming topical.

\section{MATERIALS AND Methods (MODEL)}

Earlier (see [9]), the authors proposed a set of indicators characterizing the quantitative participation of scientific organizations in the innovation activity of the above tools for implementing state innovation policy. Based on the principles of transparency and measurability, minimum sufficiency of indicators, consistency, the indicators are intended to serve the following basic objectives: the transfer of the strategy and the development program of scientific organizations to the form of integration management specific indicators; monitoring and control of the network interaction implementation of scientific organizations with the real sector; creating a basis for making managerial decisions for the medium and long-term.

Based on the developed methodological approach to assessing the effectiveness of the scientific organization's activities, which makes it possible to determine the state of these organizations integration with other participants in the national innovation system, the level of FASO scientific organizations involvement in the work of technological platforms and innovative territorial clusters has been revealed.

It is important to note that the assessment of the scientific organization's involvement in the work of the technological platforms or innovation territorial clusters does not have the ultimate goal of determining the effectiveness (or ineffectiveness) of such organization's activities. Otherwise, the results analysis obtained during the assessment of the integration interaction state between science and business makes it possible to assess the extent to which the instruments of innovative development formed within the framework of the state innovation strategy implementation are in demand by the scientific community. The information received should subsequently be used by FASO (or other executive authorities) to make management decisions aimed at identifying the reasons that have revealed the demand (or lack of demand) of technological platforms and innovative territorial clusters as tools for enhancing the scientific and technological development.

To calculate the values of the integration interaction indicators between scientific organizations and technological platforms were used various documents such as the data of the technological platforms participants lists, strategic programs of technological platforms studies, protocols of the general meetings of technological platforms participants and reports on the implementation of projects.

To calculate the values of integration interaction indicators between scientific organizations and innovative territorial clusters were used provisions about the general meeting of cluster members, lists of cluster members, lists of cluster projects, reports on their implementation, information on Cluster Development Centers.

\section{RESULTS AND DISCUSSION}

\section{A. Participation of FASO scientific organizations in the functioning of technological platforms}

According to the Russian Federation Ministry of Economic Development, as of January 1, 2017, 35 technological platforms operating in 14 directions have been officially registered in Russia. From this list, the technological platform "Innovative machine technologies of agriculture", registered in 2016, didn't enter the sample for the survey.

The study of technological platforms on the subject of scientific organizations equity participation in their activities revealed uneven distribution in the composition of functioning platforms. The largest share of scientific organizations is noted in the activities of the National Supercomputer Technology Platform and is $23.49 \%$ (Fig. 1). High share participation of FASO scientific organizations is also demonstrated by the following platforms: "Ocean Development" (20.0\%); "Technological platform of solid minerals" (19.05\%); "National Information Satellite System" (18.8\%); "Medicine of the future" (15.94\%); "Light and reliable designs" (15.38 $\%)$; "Bioenergetics" (15.04\%). The average share of FASO scientific organizations participation in the technological platforms activity is $8.94 \%$ of the organizations number. In addition, only 15 technological platforms have overcome the 8 $\%$ threshold of scientific organizations participation. The functioning of several technological platforms ("Construction and architecture", "Textile and light industry", "Managed thermonuclear fusion") is not accompanied by the involved scientific organizations.

Consideration of the dynamics of the FASO scientific organizations participated in the work of the technological platforms enabled the leaders to be identified and general trends in the susceptibility of organizations to network forms of innovation development and interaction (Fig. 2). Thus, the Institute of Chemical Physics Problems of the Russian Academy of Sciences (Moscow) demonstrated the largest number of entries in the working groups of technological platforms. High indicators also show Kutateladze Institute of Thermophysics SB RAS (Novosibirsk) - participant of seven technological platforms, The Joint Institute for High Temperatures of RAS (Moscow) - participant of seven technological platforms, Khristianovich Institute of Theoretical and Applied Mechanics. SB RAS (Novosibirsk) participant of seven platforms.

In the course of the research, using the example of the technological platform "Deep Processing of Hydrocarbon Resources", the tasks performed by scientific organizations are considered in detail. It is noted that of the 86 tasks formed in the strategic research program for the five aggregated areas, 
scientific organizations participate in the implementation of 74 tasks. The work carried out by them is financed from the federal program "Research and development in priority areas of Russian scientific and technological complex development for 2014-2020 years", as well as the funds of organizationscustomers.

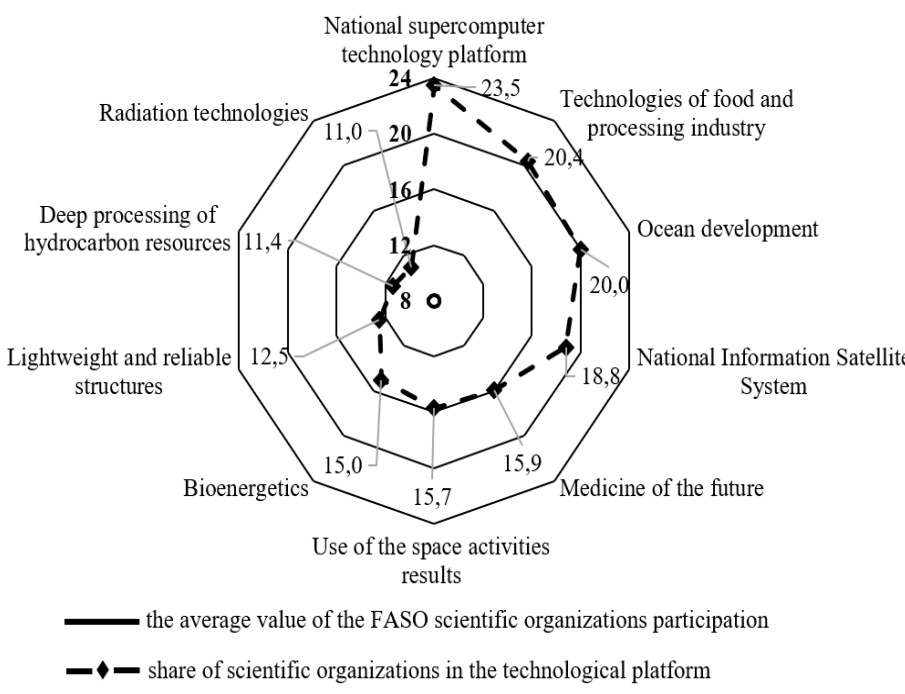

Fig. 1. Technological platforms with share participation of FASO scientific organizations exceeding 11 percent level

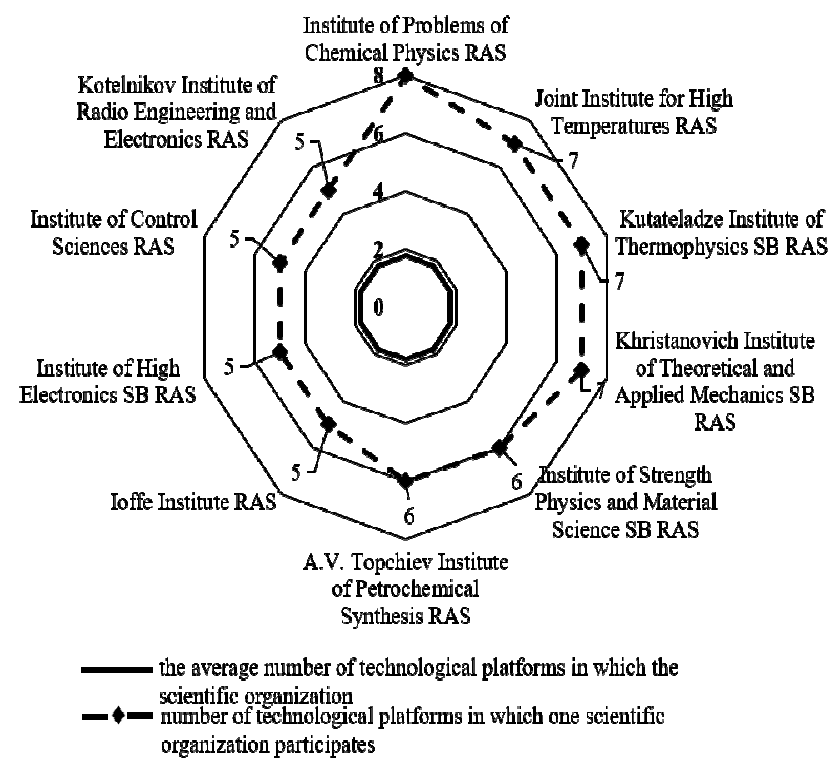

Fig. 2. FASO Scientific organizations, taking part in the activities of five or more technological platforms

High values of the scientific organizations participation index in the work of technological platforms are typical for a small number of organizations (Fig. 3). Thus, the overwhelming majority of scientific organizations participate in the work of one (123 FASO organizations) or two (34 FASO organizations) technological platforms. The number of organizations involved in the activities of four or more platforms is 17 units.

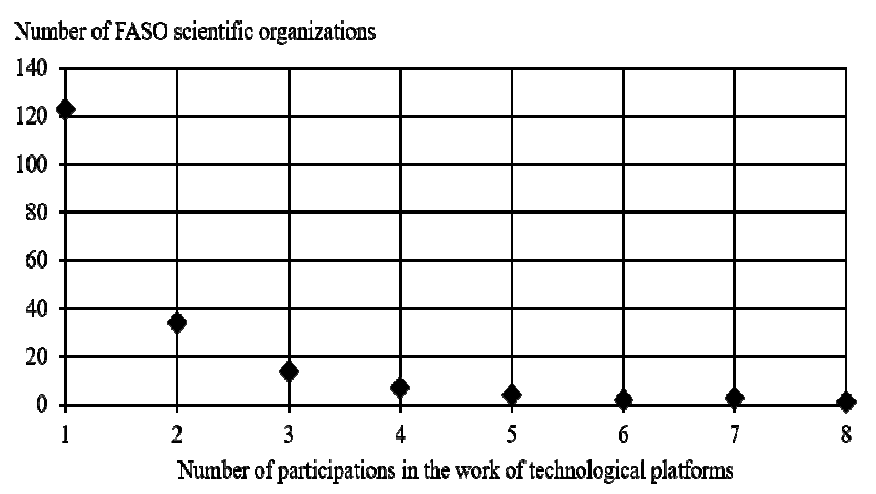

Fig. 3. The frequency of FASO scientific organizations participation in the work of technological platforms

\section{B. Participation of the FASO scientific organizations in the cluster policy implementation}

According to the Russian Federation Ministry of Economic Development, to date, 26 innovative territorial clusters operating in 19 regions of the country receive support from the federal budget through federal subsidies. To the above clusters are added 11 Megaclusters, which passed the competition in 2016.

In the course of the study, the levels of interaction between participants in innovation activity determined in relation to Megaclusters, which combined previously created innovative territorial clusters (Table 1).

The results of the evaluation procedures showed that only in the work of the five innovative Megaclusters the FASO scientific organizations are participating. The largest level of scientific organizations participation was achieved in Megacluster "Yenisei" (9.3\%). At the same time, scientific organizations located outside the cluster territory were part of the working groups of the Yenisei. The average share of FASO organizations participation in existing Megaclusters is $2.4 \%$ (Fig. 4).

It is of interest to consider the participation of scientific organizations in innovative clusters activities from the position of their distribution within the Russian Federation constituent entities (Fig. 5). For example, in the Republic of Tatarstan in the work of Megacluster "Kamsky Innovative TerritorialProduction Cluster", only one FASO scientific organization participates, located on the territory. In Novosibirsk and Tomsk regions, a little more than a third of scientific organizations are involved in the work of Megaclusters. It is noted that all FASO scientific organizations located in the Krasnoyarsk Territory take part in the work of Megacluster "Yenisei". However, it is important to emphasize here that since August 1, 2016, all FASO scientific organizations located in Krasnoyarsk have become part of the Federal Research Center "Krasnoyarsk Scientific Center of the Siberian Branch of the RAS". And now they represent one institutional (organizational) unit in information materials reflecting the work of Megacluster. 
TABLE I. PARTICIPATION OF FASO SCIENTIFIC ORGANIZATIONS IN THE WORK OF TERRITORIAL CLUSTERS

\begin{tabular}{|l|l|c|c|c|}
\hline \multicolumn{1}{|c|}{ Cluster name } & Territory & $\begin{array}{c}\text { Amount } \\
\text { FASO } \\
\text { organization } \\
\text { S on the } \\
\text { territory }\end{array}$ & $\begin{array}{c}\text { Amount } \\
\text { FASO } \\
\text { organization } \\
\text { S }\end{array}$ & $\begin{array}{c}\text { Total } \\
\text { organizatio } \\
\text { ns }\end{array}$ \\
\hline $\begin{array}{l}\text { Siberian } \\
\text { Scienceopolis }\end{array}$ & $\begin{array}{l}\text { Novosibirsk } \\
\text { region }\end{array}$ & 42 & 15 & 224 \\
\hline $\begin{array}{l}\text { Innovative cluster of } \\
\text { the Ulyanovsk region }\end{array}$ & $\begin{array}{l}\text { Ulyanovsk } \\
\text { region }\end{array}$ & 1 & 0 & 95 \\
\hline $\begin{array}{l}\text { Innovative territorial } \\
\text { aerospace cluster }\end{array}$ & Samara region & 6 & 0 & 62 \\
\hline $\begin{array}{l}\text { United Innovation } \\
\text { Cluster }\end{array}$ & $\begin{array}{l}\text { Moscow } \\
\text { region }\end{array}$ & 30 & 21 & 247 \\
\hline $\begin{array}{l}\text { Valley of Machine } \\
\text { Building }\end{array}$ & Lipetsk region & 2 & 0 & 117 \\
\hline Technopolis Enisey & $\begin{array}{l}\text { Krasnoyarsk } \\
\text { region }\end{array}$ & 11 & 14 & 150 \\
\hline Smart technologies & Tomsk region & 8 & 3 & 184 \\
\hline $\begin{array}{l}\text { Kamsky Innovative } \\
\text { Territorial and } \\
\text { Production Cluster }\end{array}$ & $\begin{array}{l}\text { Republic } \\
\text { Tatarstan }\end{array}$ & 8 & 1 & 213 \\
\hline $\begin{array}{l}\text { Lighting and } \\
\text { optoelectronic } \\
\text { instrument making }\end{array}$ & $\begin{array}{l}\text { Republic } \\
\text { Mordovia }\end{array}$ & 1 & 0 & 40 \\
\hline
\end{tabular}

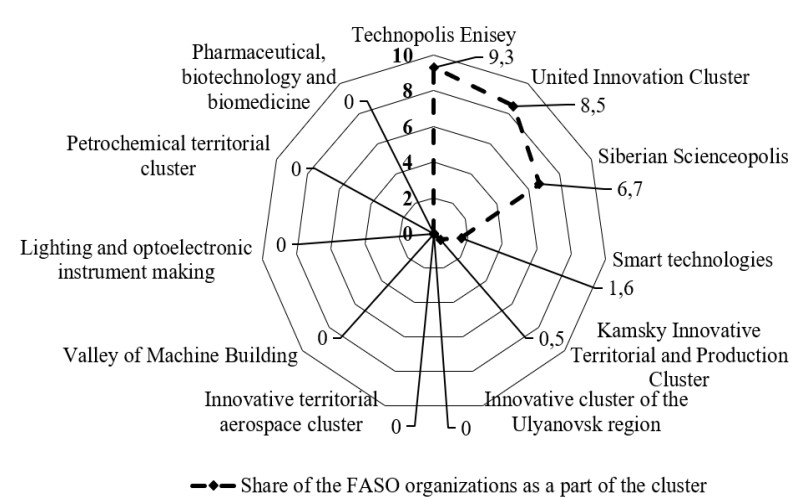

Fig. 4. The level of the FASO scientific organizations participation in the work of Megaclusters

The discrepancy between the topics of innovative clusters activity and the direction (profile) of the scientific organizations active in the regions demonstrating a low level of equity participation is traced.

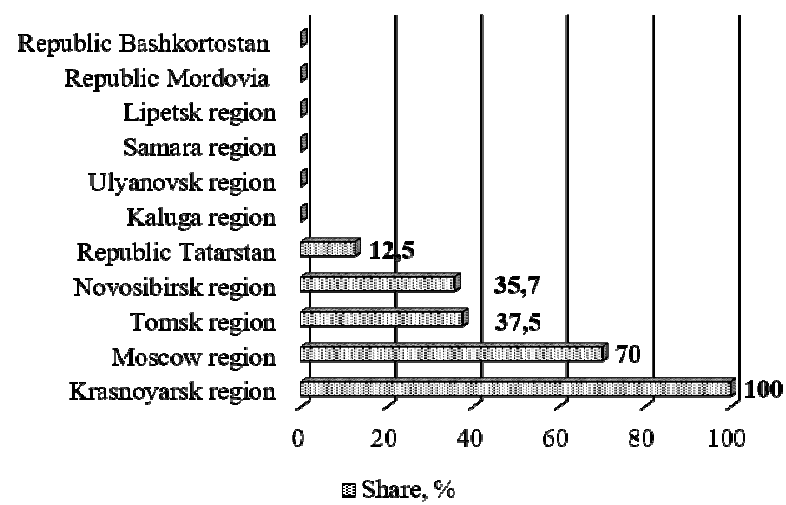

Fig. 5. The level of FASO scientific organizations equity participation in the work of Megaclusters

\section{CONCLUSION}

The attention of Russian scientists and practitioners is turned today to the Strategy of Scientific and Technological Development of the Russian Federation, effective implementation of which, according to the authors, is possible only with the effective work of national innovation system and the effective work of scientific organizations. The data of the conducted research show that technological platforms have become a more acceptable tool for the interaction of scientific organizations with the real sector. At the same time, for a significant part of the scientific organizations subordinate to the FASO, platforms, and clusters turned out to be unclaimed tools for using the results of the intellectual activity. Thus, out of more than 500 scientific organizations that passed an extraordinary performance evaluation, only one third is involved in strategic research programs implemented within the framework of technological platforms. This fact once again underscores the openness of Russia's national innovation system and predetermines the necessity for a more detailed consideration of the integration interaction instruments between subjects of science and business. For the successful implementation of the scientific and technological development strategy, it is important to identify the reasons that determine the above problem (lack of specialized technological platforms etc.).

\section{References}

[1] O.V. Glushakova, V.V. Mikhailov, "Reindustrialization and a new economy - does Russia have a chance to succeed?" [Reindustrializatsiya i novaya ekonomika - est' li u Rossii shans dobit'sya uspekha], Finance and credit [Finansy i kredit]. 2017. Vol. 1 (721). pp. 19-37.

[2] N.V. Fadeykina, S.S. Malina, T.T. Bieiadovskii, Integration of science, education and business and its role in the innovative development of the Novosibirsk Region [Integratsiya nauki, obrazovaniya i biznesa i ee rol' v innovatsionnom razvitii Novosibirskoi oblasti]. - Novosibirsk: SAFBD, 2016. -363 p.

[3] Adner R. Match your Innovation Strategy to your Innovation Ecosystem, Harvard Business Review. 2006. Vol. 84, № 4. pp. 98-110.

[4] Iansiti M., Levien R. The Keystone Advantage: What the New Dynamics of Business Ecosystems Mean for Strategy, Innovation, and Sustainability, Harvard Business School Press, Boston, MA. 2004. - 254 p.

[5] "Short moment of celebration. About how scientific discoveries are made" [Kratkii mig torzhestva. O tom, kak delayutsya nauchnye otkrytiya], M.: Science, 1988. - 336 p.

[6] G.V. Osipov, "Russian Academy of Sciences - three centuries of service to the Fatherland," [Rossiiskaya akademiya nauk - tri veka sluzheniya Otechestvu]. - M.: ISPR RAS, 2013. - 360 p.

[7] I.G. Dezhina, "Technological platforms and innovative clusters in Russia together or separately?," [Tekhnologicheskie platformy i innovatsionnye klastery v Rossii - vmeste ili porozn'?], Innovations [Innovatsii]. 2013. Vol. 2 (172). pp. 35-43.

[8] V.L. Abashkin, A.D. Boyarov, E.S. Kutsenko, "Cluster policy in Russia: from theory to practice," [Klasternaya politika v Rossii: ot teorii k praktike], Forsyte [Forsait]. 2012. Vol. 3. pp. 16-27.

[9] T.T. Bieiadovskii, "Ecosystem approach to assessing the scientific organizations performance," [Ekosistemnyi podkhod k otsenke rezul'tativnosti deyatel'nosti nauchnykh organizatsii], Innovative development of the economy [Innovatsionnoe razvitie ekonomiki]. 2017. Vol. 4 (40). pp. 37-45. 